\title{
VAN GOGH E O CAMPO DE TRIGO COM CORVOS: DA TELA AO VIDEOCLIPE
}

\author{
Maria Adélia Menegazzo* \\ Isabella Banducci Amizo* \\ Universidade Federal do Mato Grosso do Sul
}

\begin{abstract}
Resumo: Há tempos sendo tema de reflexões e discussões entre pensadores, teóricos e artistas, a relação interartes se mantém e se renova nas manifestações artísticas contemporâneas. Hoje, o elo entre as artes e as discussões sobre o tema se estendem para outros campos, indo além da literatura e da pintura, e incluindo a fotografia, o cinema e, ainda, novas mídias, como a publicidade e o videoclipe. Este artigo apresenta uma reflexão sobre o elo entre diferentes formas de arte, o engendramento de uma obra de arte em outra, demonstrando mecanismos do exercício interartes, a partir da tela de Vincent Van Gogh, Campo de trigo com corvos. Propõe-se, então, uma análise sobre a maneira como o tema da pintura, as cores azul e amarelo, bem como os corvos, aparecem em outras manifestações artísticas, neste caso a poesia ( $\grave{A}$ luz dos vegetais, de Contador Borges), o cinema (Sonhos, de Akira Kurosawa), a música e o videoclipe (Corvos sobre o campo, da banda Tantra). Como aporte teórico, são usados os conceitos de multimídia e mixmídia, de Claus Clüver, e descrição e translação pictural, de Liliane Louvel, assim como as discussões de Thiago Soares no que diz respeito a videoclipes.
\end{abstract}

Palavras-chave: Estudos interartes. Pintura. Literatura. Videoclipe. Vincent Van Gogh

Amar é um elo entre o azul e o amarelo

(Paulo Leminski)

Anu. Lit., Florianópolis, v. 20, n. 2, p. 84-97, 2015. ISSNe 2175-7917 


\section{Introdução}

O elo entre as diferentes formas de arte, as relações e comparações entre elas, são discussões que remontam à Antiguidade e percorrem toda a História até a atualidade. Por volta dos anos 14 e 13 a.C., Horácio escreve a Epístola aos Pisões, na qual o conceito de ut pictura poesis é definido, tratando da relação entre pintura e poesia. Segundo ele, "Poesia é como pintura; uma te cativa mais, se te deténs mais perto; outra, se te pões mais longe; esta prefere a penumbra; aquela quererá ser contemplada em plena luz, porque não teme o olhar penetrante do crítico" (HORÁCIO, 2000, p. 65). Séculos depois, o tema é abordado por Leonardo da Vinci, em seu Tratado sobre a pintura (2005), no qual estabelece um paralelo entre as artes, buscando demonstrar a superioridade da pintura sobre as outras, bem como sobre todas as atividades humanas, constituindo a forma mais nobre, acabada e elevada de todo o conhecimento. Gotfried Lessing, num momento de conflito entre o neoclassicimo e o romantismo, escreve o Laocoonte (2005), também discutindo sobre a pintura e a poesia, definindo-as como artes do espaço e artes do tempo. O conceito do dramaturgo e crítico de arte alemão vigora até o século XIX, quando Charles Baudelaire rompe com o modo como até então se pensam essas relações. Em "A especificidade das artes" (2005), Baudelaire discute assuntos como a correspondência entre as artes, excluindo a ideia de paralelo ou comparação, e ocupa-se dos efeitos e da analogia dos sentimentos provocados por elas.

Hoje, o elo entre as artes e as discussões sobre o tema se estendem para outros campos, indo além da literatura e da pintura, e incluindo a fotografia, o cinema e, ainda, novas mídias, como a publicidade e o videoclipe. Conforme aponta Maria Adélia Menegazzo, "na literatura, desde há muito, o poeta é um bricoleur, um ser pleno de referências com as quais constrói seu universo poético. Hoje, o poeta atua em todas as frentes artísticas, inclusive no universo das artes midiáticas e no mundo virtual" (MENEGAZZO, 2011, p. 2). E complementa:

mais do que nunca, amparada pelas tecnologias à disposição do nosso cotidiano, a poesia aprofunda sua dimensão visual e se apresenta em suportes que vão do livro ao vídeo, do tablet, ao telefone celular, entre inumeráveis outros. A incessante recusa de uma abordagem direta da realidade desde o modernismo implicou uma nova ontologia da arte que, para além de sua autonomia, aposta na ampliação dos seus limites. Uma tal situação, para a poesia contemporânea, abre um espaço considerável no diálogo interartes, implicando também a presença de reflexões da teoria da linguagem no campo das artes visuais. A relação entre arte e literatura pode atingir níveis variados de manifestação e favorecer outros tipos de abordagem" (MENEGAZZO, 2011, p. 3).

Menegazzo faz tal afirmação ao discutir o engendramento de uma obra de arte em outra, demonstrando mecanismos do exercício interartes em poemas da literatura brasileira 
contemporânea que mantêm relação com as artes visuais. Proposta semelhante é aqui apresentada, tendo como enfoque a tela Campo de trigo com corvos (óleo sobre tela, 50,5 $\mathrm{x}$ 100,5cm, Museu Van Gogh, Amsterdam), de Vincent Van Gogh (Figura 1), e a maneira como seu tema, o azul e o amarelo, bem como os corvos, aparecem em outras manifestações artísticas, neste caso o cinema (Sonhos, de Akira Kurosawa), a música e o videoclipe (Corvos sobre o campo, da banda Tantra), além da poesia.

Figura 1 - Van Gogh - Campo de trigo com corvos. 1890. Óleo sobre tela, 50,5 x 100,5cm

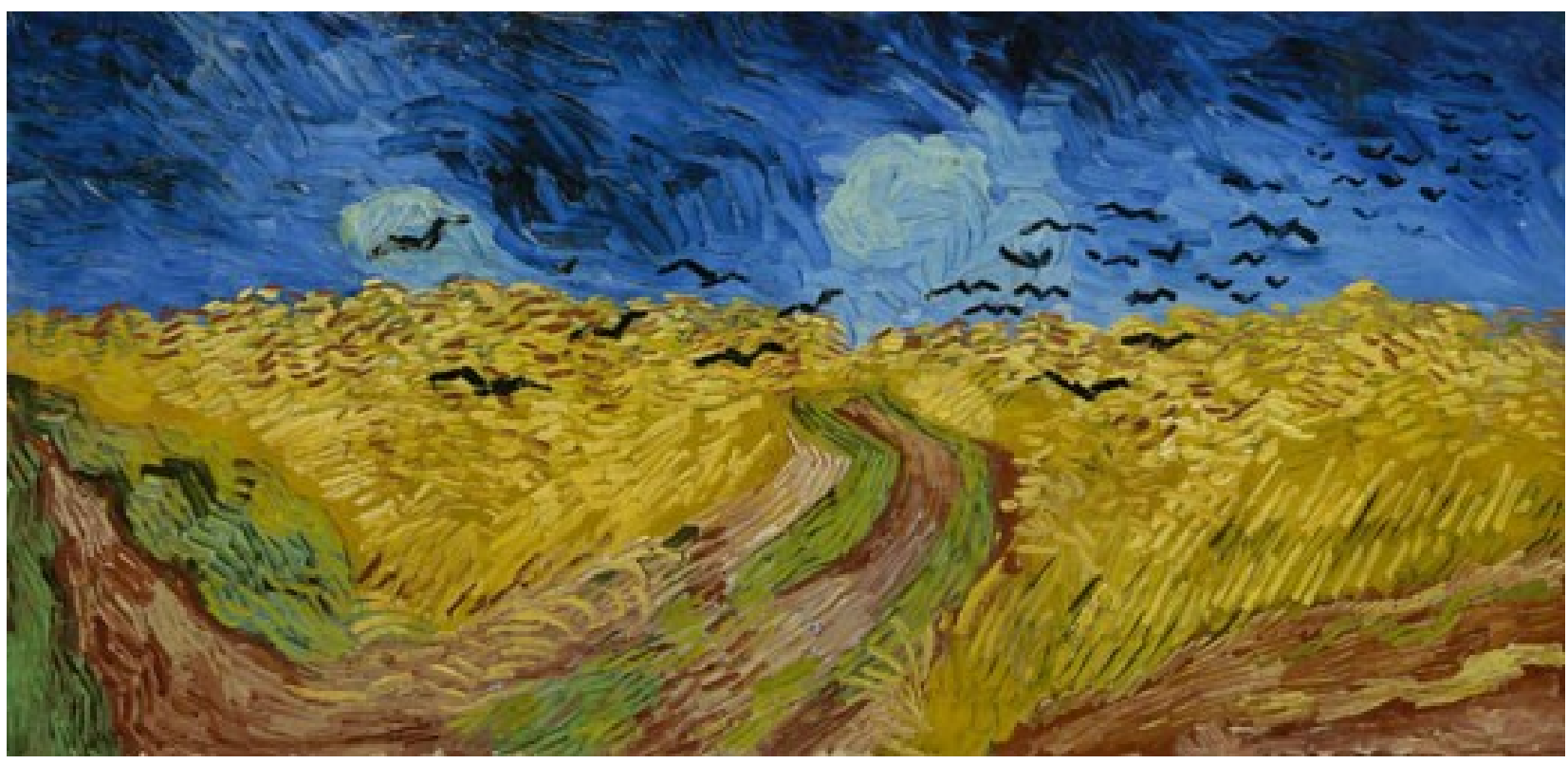

Fonte: Museu Van Gogh, Amsterdam.

\section{Estudos interartes e a tela de Van Gogh}

É relevante, antes que se pense especificamente nessas obras, apontar algumas questões teóricas que permeiam a abordagem, no que diz respeito aos estudos interartes. Claus Clüver, no texto "Inter textus / Inter artes / Inter media" (2006), discute os conceitos de mídia e estudos intermidiáticos, propondo que a intermidialidade amplia a noção do que costumeiramente se entende como arte, incluindo o Cinema, o Vídeo, a Televisão, o Rádio e ainda as mídias eletrônicas e digitais (CLÜVER, 2006, p. 18-19). O teórico indica então que tanto na construção quanto na interpretação textual são utilizados elementos dessas diversas mídias, e os Estudos Interartes abrangem aspectos transmidiáticos e transposições intersemióticas, havendo mudanças de um sistema de signo para outro, assim como de uma mídia para outra. A partir disso estabelece a definição de textos multimídia e mixmídia, definindo que: 
Um texto multimídia compõe-se de textos separáveis e separadamente coerentes, compostos em mídias diferentes, enquanto que um texto mixmídia contém signos complexos em mídias diferentes que não alcançariam coerência ou auto-suficiência fora daquele contexto (CLÜVER, 2006, p. 19).

Serão importantes para se pensar na relação interartes a partir da tela de Van Gogh, assim como os apontamentos de Clüver, as acepções de Liliane Louvel de descrição e translação pictural. Esta constitui-se numa translação transmidiática, com passagens de um significante a outro, mas de naturezas diferentes, do pictural para o linguístico e, no caso aqui abordado, ainda para a letra da música (também linguística) e o vídeo (com traços picturais). A descrição pictural é assim definida:

\begin{abstract}
Estabeleçamos que uma descrição será dita 'pictural' quando a predominância de 'marcadores' da picturalidade, aquilo que faz com que uma imagem seja artística, seja um artefato, será irrefutável e que passarão a segundo plano a intenção didática, as referências aos saberes matésico, mimésico, etc. Pelo menos, teremos uma emulsão, jamais uma fusão total, seja um iconotexto. Haverá sempre um traço, o vestígio de um no outro. O iconotexto funcionará pois como um bi-media sobre o modo binário, modo clássico da variação do texto, de acordo ou em desacordo com ele, um híbrido do texto, ritmado pelas aparições da imagem (LOUVEL, 2006, p. 195)
\end{abstract}

As reflexões de Louvel e Clüver servirão de aporte para as abordagens feitas a seguir. Dito isso, cabe então tratar dos diálogos interartes a partir de Van Gogh e sua tela. Um primeiro aspecto a ser apresentado é a relação entre a pintura e a poesia, tratada no artigo de Menegazzo (2011), que analisa o poema “À luz dos vegetais”, de Contador Borges.

Auvers-sur-oise, 1890
À luz
Dos vegetais
As cores fervem
Na paleta
Uma rajada de tinta
Corta súbito
A fulva paisagem
Entre corvos
Trigais sombras
Para espanto
Das esferas
Enquanto a orelha
Sangra de nudez
A alma se banha
No fogo
Das papoulas!

A autora percebe o vínculo da poesia com a obra do pintor holandês por meio de diversas referências. Primeiramente, a epígrafe (Auvers-sur-oise, 1890) aparece como 
indicativo espaço-temporal do local e ano da morte do artista, e, ainda, há menção da situação em que neste momento se encontrava, pintando a tela Campo de trigo com corvos. Menegazzo aponta a alusão à alta incidência de luz e o uso de cores quentes, ao encantamento com os campos de trigo relatados em carta à mãe, à amputação de parte da própria orelha, acabando por se constituir numa síntese biográfica de Van Gogh e o jogo entre vida e morte, paixão e arte. Segundo ela, na poesia "estabelece-se um ciclo enunciado em apenas quatro verbos: 'fervem', 'corta', 'sangra' e 'se banha'. Nessa medida, as cores fervem, as tintas cortam, a orelha sangra e a alma se banha no fogo das papoulas" (MENEGAZZO, 2011, p. 4).

Assim como na poesia, a referência à tela de Van Gogh no cinema também é discutida por Menegazzo. O filme Sonhos (1990), do cineasta japonês Akira Kurosawa, é composto por oito episódios, sendo um deles denominado "Corvos". Neste, o personagem, um pintor alter-ego de Kurosawa, caminha pelo museu e, observando as telas do artista holandês, transporta-se para uma delas. As referências são evidentes. O jovem pintor passeia por diferentes cenários, todos quadros de Van Gogh, sendo perceptíveis as pinceladas, as texturas e os detalhes de desenhos e pinturas. O próprio artista aparece, interpretado por Martin Scorsese, com uma sutura na orelha, e em diálogo acerca de sua relação com a natureza e seu modo obsessivo de pintar. Por fim, o personagem observa Van Gogh se afastar por um caminho que corta o trigal, enquanto corvos aparecem (Figura 2).

Figura 2 - Cena do filme: Sonhos (Akira Kurosawa, 1990).

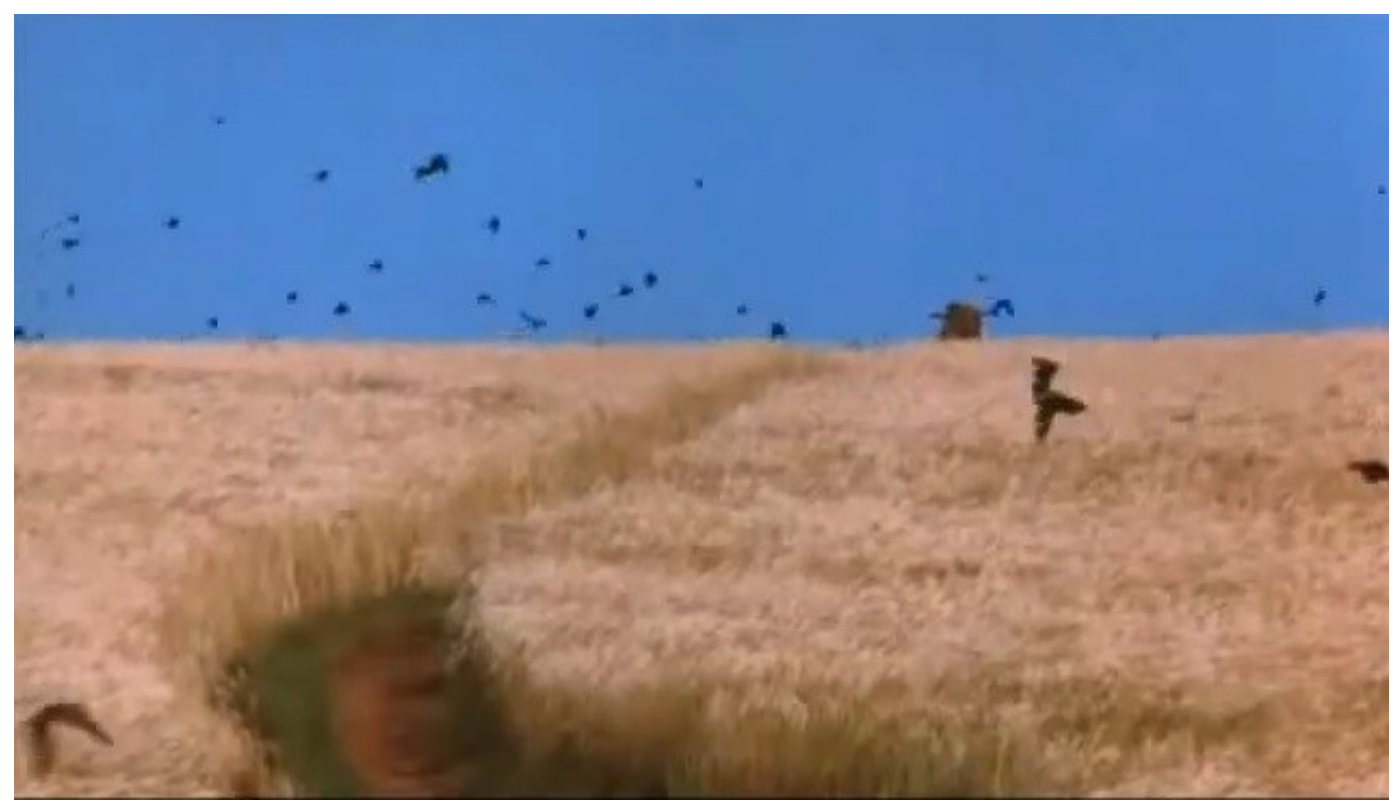

Fonte: youtube.com

A presença das cores usadas por Van Gogh no filme do cineasta japonês é algo a se destacar. Hadija Chalupe da Silva indica que, no cinema, a cor cumpre a função de 
valorização da atmosfera que o diretor propõe para atingir o público, possibilitando "uma interpretação poética interligada a imagem e ao som... e o cinema de Kurosawa é um dos maiores representantes, pois a cor e não a forma que determinava o conteúdo expressivo de seus filmes" (SILVA, 2014, p. 1). O crítico de cinema José Carlos Avellar observa que:

\begin{abstract}
há muito de Van Gogh no cinema de Kurosawa. Não se trata de traduzir uma forma, a pintura, numa outra, o cinema, mas de construir uma estrutura ou narrativa cinematográfica em diálogo com a de Van Gogh - fazer um filme assim como o pintor pintava; alterar a cor, a forma, o gesto, para torná-lo mais expressivo e menos conforme. Um cinema como a pintura que saia do impulso de cortar da natureza o que não serve para a natureza do filme, ou do quadro, o que não serve para a expressão (AVELLAR, 1990, p. 1).
\end{abstract}

A colocação de Avellar sobre a relação entre a pintura de Van Gogh e o cinema de Kurosawa está de acordo com a ideia de Claus Clüver ao tratar das transposições intersemióticas. Conforme aponta, não são pertinentes questões como a fidelidade e a adequação para com o texto-fonte, neste caso a pintura, "simplesmente porque a nova versão não substitui a original" (2006, p. 17). As possíveis leituras de um mesmo objeto, como aponta ainda Menegazzo, não se reduzem uma à outra, nem mesmo ao objeto de origem. Tratando, então, do poema e do filme que se referem ao Campo de trigo com corvos, afirma:

Temos assim, duas linguagens diferentes que se complementam para falar o mesmo episódio e permitir uma leitura ampliada de um único objeto. A poesia reduzindo-o a poucas palavras investe nos cortes e no espaçamento da página, configurando momentos de silêncio e de ritmo acentuado. Observe-se ainda que o posicionamento das palavras em ziguezague provoca uma leitura rápida e vertiginosa do poema, produzindo o efeito de um instantâneo. O cinema, mais literal, reconstitui o episódio no tempo, ainda que o passeio do personagem pelas telas de Van Gogh confirme seu caráter onírico, transportado pelo som da sinfonia de Beethoven. Uma leitura não se reduz à outra, mas ambas se tocam em algumas arestas do diálogo artístico como recortes ficcionais de uma mesma biografia (MENEGAZZO, 2011, p. 5).

Além da poesia e do cinema, os diálogos com a tela de Van Gogh aparecerão também na música e no videoclipe. Em 1996, a banda brasileira Tantra lançou o disco Eles não eram nada, do qual faz parte a música "Corvos sobre o campo", composta por Fred Nascimento (guitarrista e vocalista) e Gian Fabra (baixista). Os três versos iniciais configuram-se como um procedimento ecfrástico, assim como a última estrofe, havendo uma espécie de descrição da pintura do artista holandês, ou ainda o que Louvel define como descrição pictural.

Céu azul / Campo amarelo / Corvos avançam em nossa direção

E não há porque se assustar / Deixa o medo entrar no seu coração

Tudo o que eu fiz foi por amor / Acho até que encontrei / O motivo de um final feliz 
Nunca imaginei em nosso fim / Construir meu castelo / Com as pedras que eu te atirei

Ieieie / Nada vai durar / As maldades serão coisas belas enfim

Nada vai durar tanto assim / Abra os olhos, então / Olha os corvos sobre o campo

Céu azul / Campo amarelo / Corvos avançam em nossa direção

Vermelhos caminhos / Ecos de cores / Vaga pulsação / De clara escuridão

É interessante notar aqui a maneira como se estabelece o diálogo interartes. Nascimento e Fabra valem-se da referência à pintura para tratar de assuntos não necessariamente nela presentes, mas possíveis de serem lidos a partir de uma interpretação dos compositores. Em entrevista ao jornal Folha de São Paulo, o vocalista da banda afirma: "Van Gogh é tão rock'n'roll. Une a violência à doçura" (GRILLO, 1996). A agressividade e a delicadeza serão, portanto, aquilo que abstraído da tela se tornará tema para a composição da música, por meio da descrição. Como aponta Louvel (2006, p. 200-201): "Uma de suas funções maiores seria a função poética, com a descrição pictural funcionando como um tropo que operaria um desvio em direção a um sentido 'figurado', uma 'translação'”. Este sentido figurado é evidenciado na citação das cores fria e quente, o azul e o amarelo, como representação da doçura e da violência coexistentes de que fala Nascimento, a "clara escuridão" nos tortuosos "vermelhos caminhos". Além disso, os corvos constituem uma metáfora a problemas, dificuldades e medos que precisam ser encarados, não devendo ser temidos. É o que se percebe nos versos "Corvos avançam em nossa direção / E não há porque se assustar / Deixa o medo entrar no seu coração" e também "Nada vai durar tanto assim / Abra os olhos, então / Olha os corvos sobre o campo".

A relação interartes a partir da pintura de Van Gogh pode não ser evidente para um público que desconheça a obra do pintor holandês, já que não há, por exemplo, qualquer menção a seu nome. Como indica Louvel, a descrição pictural afeta o receptor, "uma vez que o leitor deverá 'saber' reconhecer o pictural, abrir seu grande livro de imagens, revisitar seu "museu imaginário" (LOUVEL, 2006, p. 203). Todavia, as referências se tornam mais evidentes ao serem explicitadas no videoclipe produzido para divulgação da música. Dirigido pelo designer e diretor de arte brasileiro Luiz Stein, o videoclipe de "Corvos sobre o campo" (1996) tem como um dos cenários principais a própria tela em dimensões ampliadas, onde é apresentada a performance da banda (Figura 3). 
Figura 3 - Videoclipe da música Corvos sobre o campo, banda Tantra, 1996.

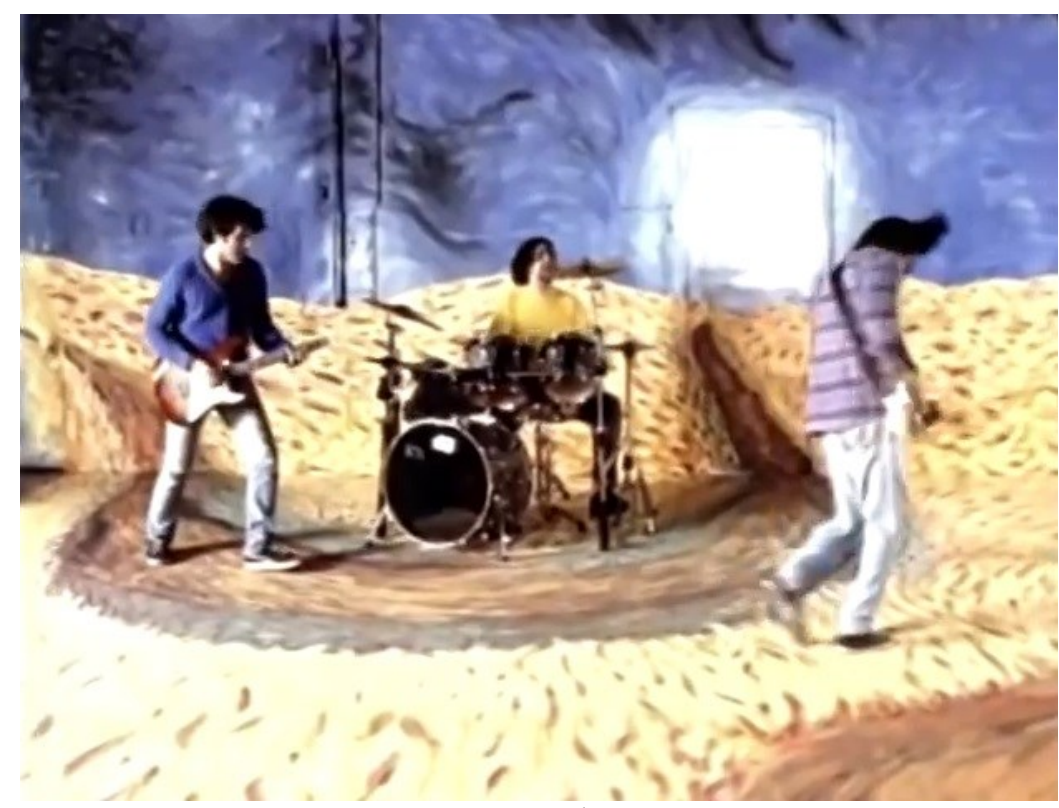

Fonte: youtube.com

Ainda, na cena de abertura, assim como na de encerramento, é visto um personagem representando o pintor, com um chapéu de palha e pincel na mão, observando a tela e nela pintando os corvos (Figuras 4). Além dessas, outras imagens são exibidas, remetendo à letra da música e a aspectos de Campo de trigo com corvos, ou não.

Figura 4 - Videoclipe da música Corvos sobre o campo, banda Tantra, 1996.

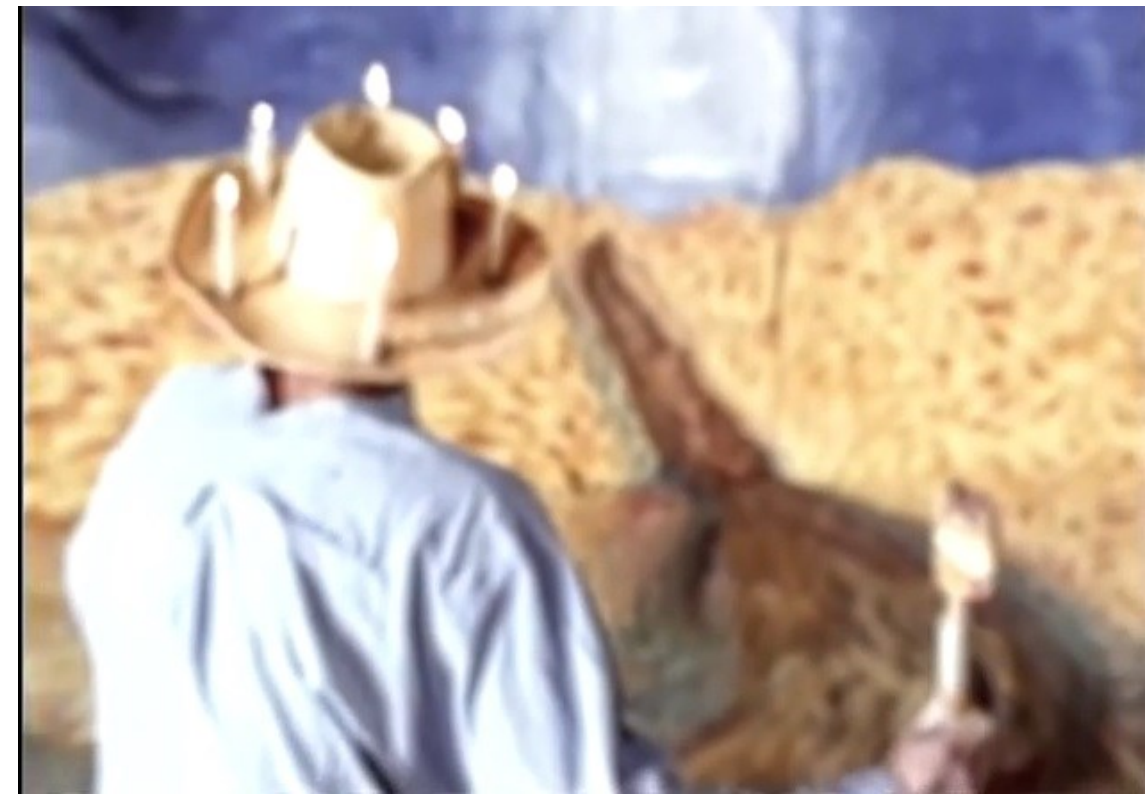

Fonte: youtube.com

De acordo com Claus Clüver, ao pensar em intermidialidade, os videoclipes podem ser reconhecidos como mixmídia. Para ele, 
os videoclipes representam uma mídia própria 'integral' na terminologia sancionada pela Inermidialidade. Eles são textos mixmídia, compostos pela união de um texto multimídia e de uma montagem de textos visuais produzido para ter sua trilha sonora vendida separadamente (música e palavras: textos multimídia), o videoclipe contém também um caleidoscópio de videotextos visuais, que mostram os músicos num ambiente que se altera continuamente e, além disso, momentos narrativos, fragmentos de dança, cenas em ambientes externos e internos e (em medida crescente) efeitos visuais produzidos puramente por computador. Enquanto muitas dessas imagens podem ser relacionadas ao texto apenas de modo associativo, sem o som elas perdem também esse sentido e os ritmos de sua montagem perdem facilmente seu efeito sem os ritmos da música. O fato de que o texto visual não é nem coerente nem auto-suficiente, não podendo, consequentemente, ter existência separada, faz do videoclipe como um todo um texto mixmídia" (CLÜVER, 2006, p. 20).

Assim como Clüver menciona um caleidoscópio de videotextos presentes no videoclipe, Thiago Soares, no livro Videoclipe: o elogio da desarmonia (2012) refere-se à sensação caleidoscópica a partir dele causada, no diálogo entre música e imagem. O diálogo e a consequente sensação despertada por essa mídia estão atrelados aos conceitos de paisagem sonora e esferas de som, definidos pelo autor. Para ele, a paisagem sonora "configura-se num constituinte sinestésico: é música coisificada em imagem, gerando um efeito virtual de ouvir algo e 'estar' na música. Ou, 'estar' no som” (SOARES, 2012, p. 43); e as esferas de som constituem-se de "elementos que podem identificar uma referência sinestésica entre a música e a imagem" (SOARES, 2012, p. 44).

Soares aponta a citação como a característica mais comum do videoclipe, assim como a colagem eletrônica, com o uso de imagens de diferentes naturezas, agregando conceitos do cinema, da televisão e da publicidade. Considera-o, com isso, um híbrido, no qual forma e conteúdo são interdependentes. Por outro lado, suas unidades são independentes; as cenas são entrecortadas; os cortes, a montagem, a passagem de um quadro a outro são rápidos; a descontinuidade e a desarmonia são perceptíveis, mas, apesar disso, formam um objeto único e coerente. O autor aborda ainda o aspecto transtemporal dos videoclipes, havendo deslocamentos, convivência e renovação de tradições, notando-se uma espécie de estética da homenagem. Afirma assim que:

[as] imagens promovem uma mescla de épocas distintas, convivendo de uma forma marcadamente diegética. A transtemporalidade no videoclipe promove, assim, a inserção de referências de época, anulando uma suposta hierarquia do passado sobre o presente. O presente é uma articulação entre como este passado é visto e como o passado gostaria de ser visto. A transtemporalidade tem a função de se articular às formas narrativas presentes no videoclipe, propondo a junção do antigo não só como reverência, mas, sobretudo, como negociação do passado com o presente (SOARES, 2012, p. 50).

Tais características apresentadas por Thiago Soares são verificáveis no videoclipe da música "Corvos sobre o campo". Como foi dito anteriormente, a tela e o próprio artista 
aparecem como cenário e personagem, compondo uma clara citação, assim como o uso do azul e do amarelo. Há várias mudanças de locação, entretanto essas cores aparecem constantemente na iluminação e, do mesmo modo, no figurino dos membros da banda (Figuras 5, 6 e 7).

Figura 5 - Videoclipe da música Corvos sobre o campo, banda Tantra, 1996.

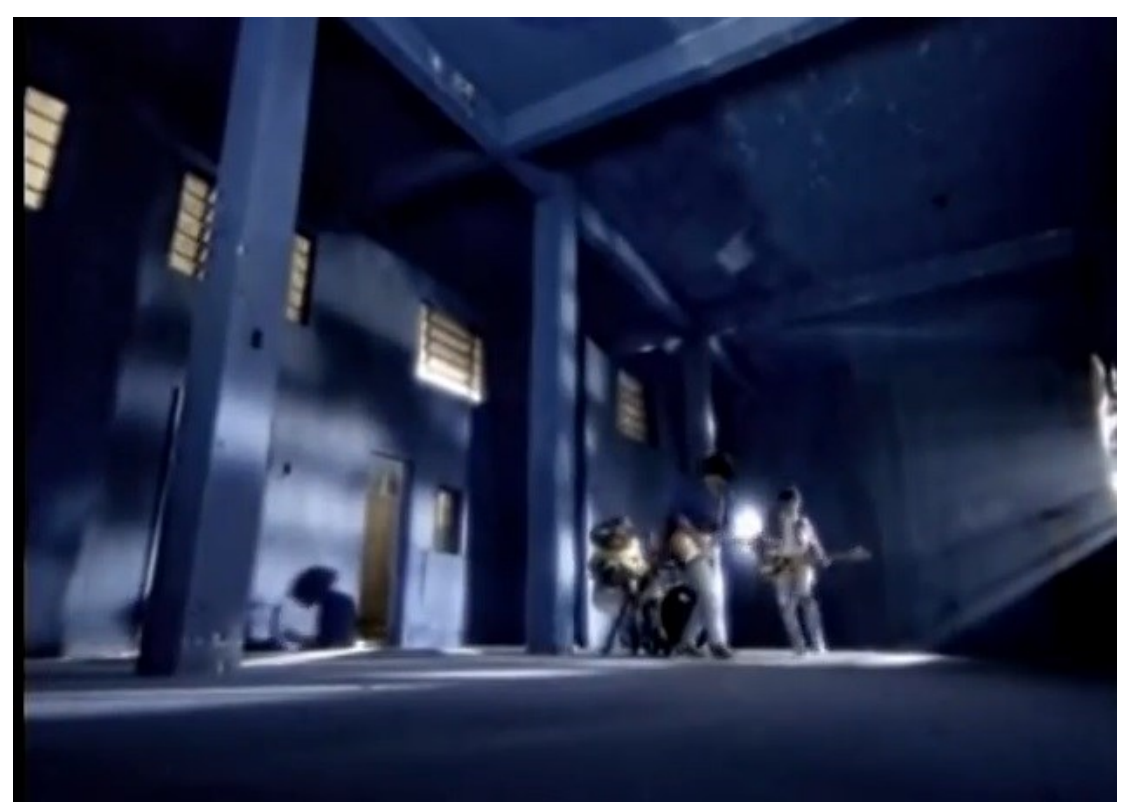

Fonte: youtube.com

Figura 6 - Videoclipe da música Corvos sobre o campo, banda Tantra, 1996

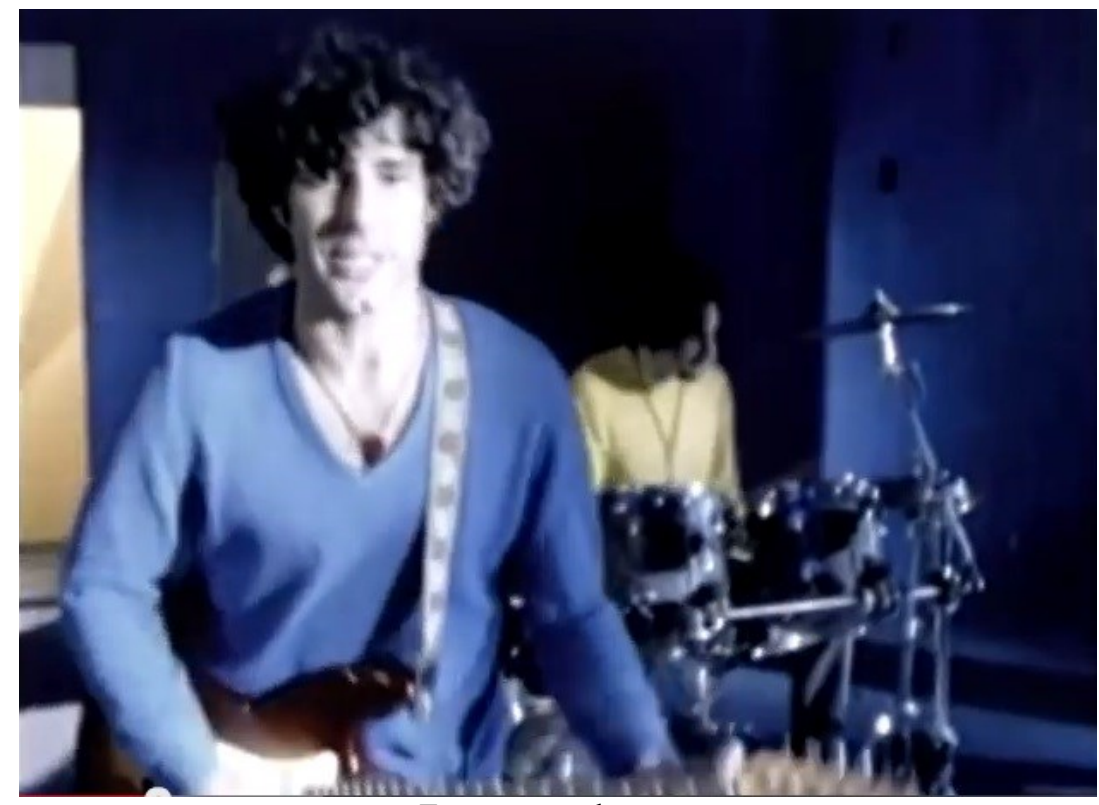

Fonte: youtube.com 
Figura 7 - Videoclipe da música Corvos sobre o campo, banda Tantra, 1996

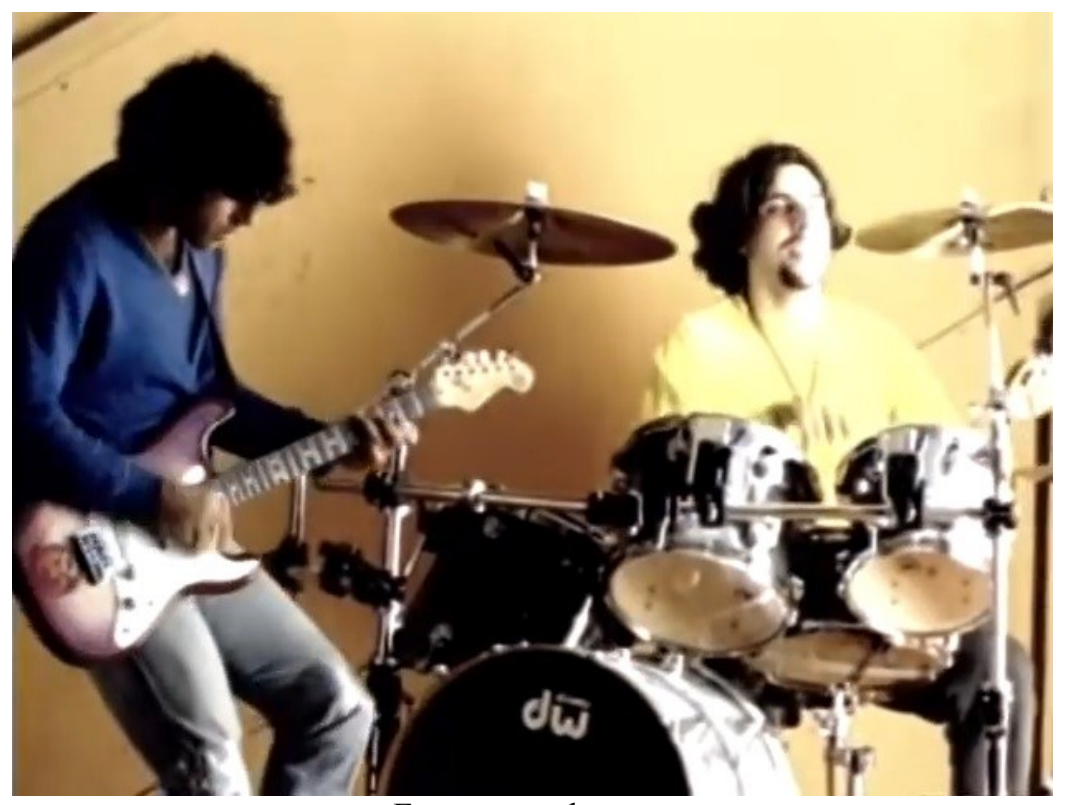

Fonte: youtube.com

As colagens, imagens sobrepostas, descontínuas e desarmônicas são mostradas em ritmo acelerado. Um corvo aparece quase de maneira imperceptível, diversas vezes, em frações de segundo, em um cenário vermelho, remetendo aos "vermelhos caminhos" mencionados na canção. Há ainda cenas em que se manipulam tintas com as cores da tela de Van Gogh (Figuras 8 e 9) e são mostradas mãos sujas por elas (Figura 11). O diálogo interartes é assim evidente, relacionando-se pintura, música e videoclipe.

Figura 8 - Videoclipe da música Corvos sobre o campo, banda Tantra, 1996

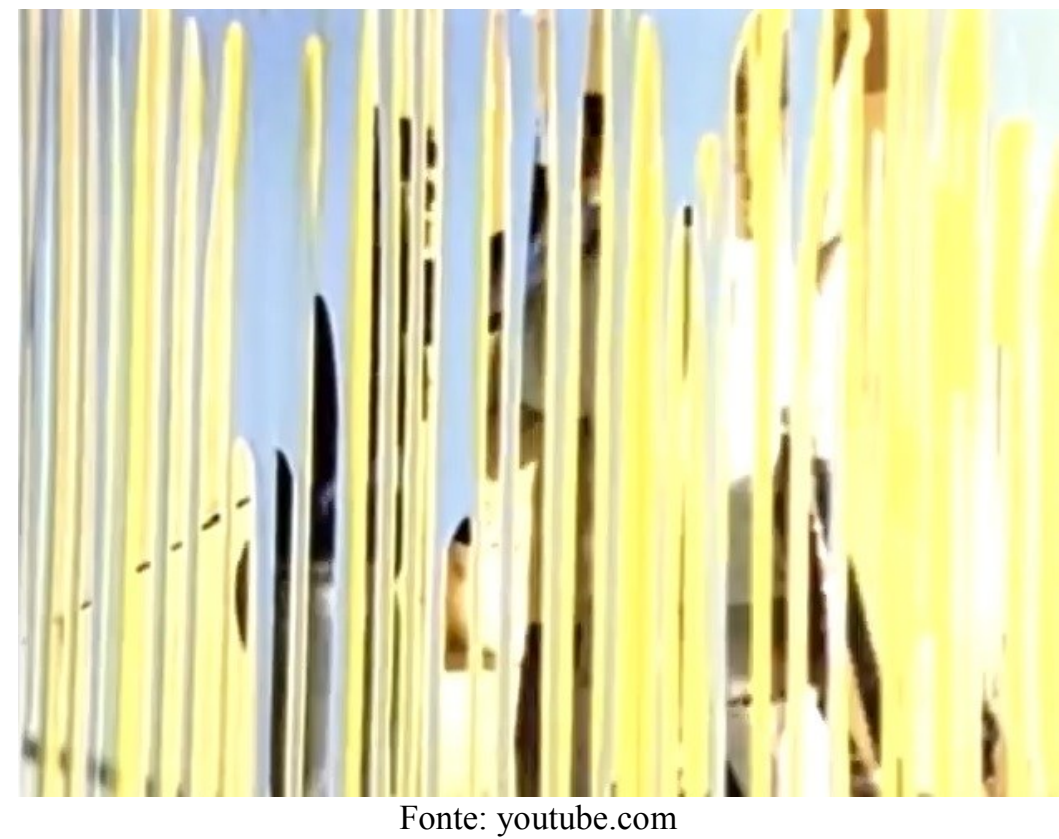


Figura 9 - Videoclipe da música Corvos sobre o campo, banda Tantra, 1996

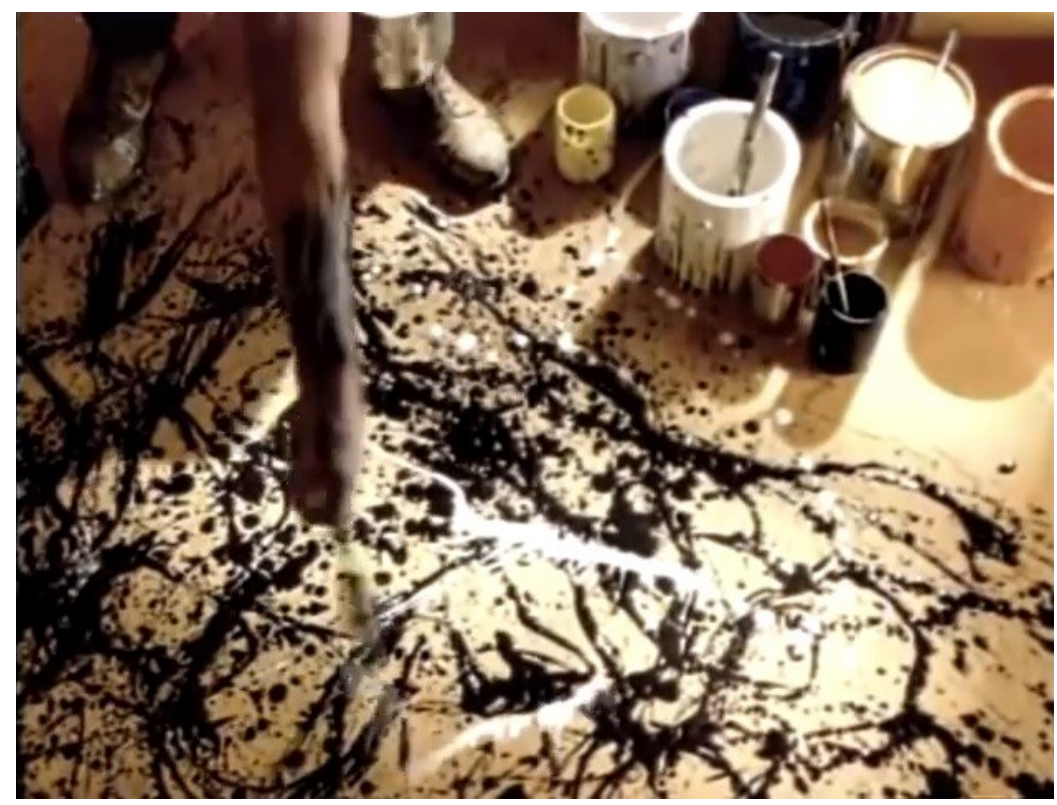

Fonte: youtube.com

Figura 10 - Videoclipe da música Corvos sobre o campo, banda Tantra, 1996

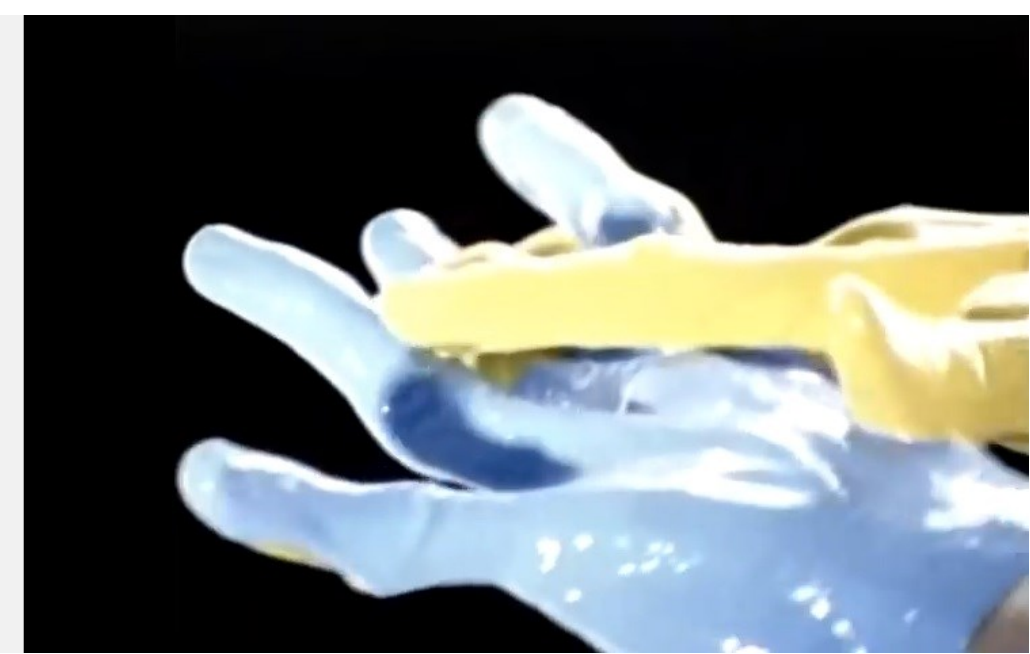

Fonte: youtube.com

\section{Considerações finais}

Cabe destacar, por fim, o aspecto transtemporal mencionado por Thiago Soares e o fato de o videoclipe acabar por se constituir, em função de suas características, como um resumo do estilo pós-modernista. É o que afirma Angela Prysthon, no prefácio do livro de Soares, elencando aspectos como o pastiche, a hiper-realidade, a volta a algumas formas tradicionais de representação, o apelo a uma certa nostalgia e uma tradição pop (PRYSTHON, 2012, p. 11-12). De maneira mais ampla, é possível pensar a partir não só do videoclipe, mas de todos os diálogos entre mídias e artes aqui apresentados, na relação do artista com o tempo. 
Maria Adélia Menegazzo, referindo-se a poetas brasileiros contemporâneos, afirma que a possibilidade de atuação em diversas frentes artísticas implica:

\begin{abstract}
a necessidade de o poeta não apenas possuir um olhar crítico sobre seu tempo, mas também um olhar reflexivo sobre o mundo e sobre sua obra. Para tanto, toma distância. Nessa démarche, o poeta representa uma "fratura": é aquele que impede o tempo de se refazer, mas que também une os fragmentos sem apagar seus vestígios. O poeta contemporâneo, ou pelo menos uma vertente dessa poesia, exercita assim a função de pensar a arte a partir da própria arte para expor-se no mundo (MENEGAZZO, 2011, p. 2).
\end{abstract}

Há tempos sendo tema de reflexões e discussões entre pensadores, teóricos e artistas, é possível perceber como a relação interartes se mantém e se renova nas manifestações artísticas contemporâneas. Pintura, poesia, cinema, música e videoclipe, textos e imagens, colocados em diálogo, propiciam aberturas para os estudos sobre a arte e o fazer artístico.

\title{
Referências
}

AVELLAR, José Carlos. O cinema no túnel de Van Gogh. 1990. Disponível em:

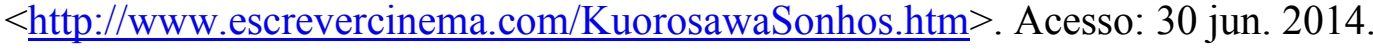

BAUDELAIRE, Charles. A especificidade das artes. In: LICHTENSTEIN, Jacqueline. $A$ pintura. Textos essenciais. v. 7, O paralelo entre as artes. São Paulo: Ed. 34, 2005, p. 102113.

CLÜVER, Claus. Inter textus / Inter artes / Inter media. Aletria: revista de estudos de literatura, Belo Horizonte, v. 14, jul-dez 2006.

GRILLO, Cristina. Ex-Legião Urbana lidera banda Tantra. Folha de São Paulo. 3 dez. 1996.

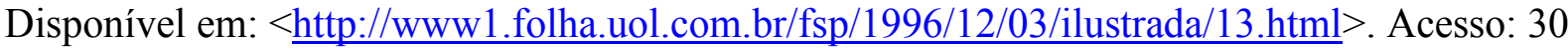
jun. 2014.

HORÁCIO. Arte poética ou Epístola aos Pisões. São Paulo: Cultrix, 2000.

KUROSAWA, Akira. $\quad$ Sonhos. $1990 . \quad$ Disponível em: $<$ https://www.youtube.com/watch? $=$ TgSIRjyQOgA\&feature=youtube gdata player $>$.

Acesso: 30 jun. 2014.

LESSING, Gotfried. Laocoonte. In: LICHTENSTEIN, Jacqueline. A pintura. Textos essenciais. v. 7, O paralelo entre as artes. São Paulo: Ed. 34, 2005, p. 82-92.

LOUVEL, Liliane. A descrição "pictural”. Por uma poética do iconotexto. In: ARBEX, Márcia (org). Poéticas do visível: ensaios sobre a escrita e a imagem. Belo Horizonte: Programa de Pós-Graduação em Letras: Estudos Literários, Faculdade de Letras da UFMG, 2006, p. 191-220.

MENEGAZZO, Maria Adélia. Quando a arte se torna poesia. Cadernos de Semiótica Aplicada. Araraquara, v. 9, n.2, dezembro de 2011. UNESP. 
PRYSTHON, Angela. Prefácio. O videoclipe ou a forma cultural do pós-modernismo. In: SOARES, Thiago. Videoclipe: o elogio da desarmonia. João Pessoa: Marca de Fantasia, 2012.

SILVA, Hadija Chalupe da. Akira Kurosawa. Disponível em: $<$ http://www.ufscar.br/ cinemais/artakira.html>. Acesso: 30 jun. 2014.

SOARES, Thiago. Videoclipe: o elogio da desarmonia. João Pessoa: Marca de Fantasia, 2012.

TANTRA. Corvos sobre o campo. 1996. Disponível em: $<$ http://m.youtube.com/watch?v=tSjJwaSZO50>. Acesso: 30 jun. 2014.

VINCI, Leonardo da. Tratado da pintura (“O paragone”). In: LICHTENSTEIN, Jacqueline. $A$ pintura. Textos essenciais. v. 7, O paralelo entre as artes. São Paulo: Ed. 34, 2005, p. 17-27.

[Recebido em maio de 2015 e aceito para publicação em setembro de 2015]

\section{Van Gogh and the wheatfield with crows: from the painting to the videoclip}

Abstract: For a long time being a theme for reflections from scholars, academics and artists, interart relations maintains its importance and is renewed in contemporary artistic expressions. Today, the link between kinds of art and the discussions on the topic extend to other fields, going beyond literature and painting, and including photography, cinema and also new medias, such as advertising and videoclip. This article focuses on the link between different art forms, the engendering of an art in another, demonstrating mechanisms of the interart exercise, from the Vincent van Gogh painting, Wheatfield with Crows. It is proposed an analysis of how the subject of the painting, the colors blue and yellow, as well as the crows, appear in other art forms, in this case poetry ( $\grave{A}$ luz dos vegetais, of Contador Borges), cinema (Dreams, of Akira Kurosawa), music and videoclip (Corvos sobre o campo, of Tantra). As theoretical base are used the concepts of multimedia and mixmídia, of Claus Clüver, and description and pictorial translation, of Liliane Louvel, as well as Thiago Soares discussions about videoclips.

Keywords: Interart studies. Painting. Literature. Videoclip. Vincent Van Gogh.

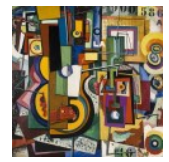

